\title{
TRATAMENTO DE EFLUENTES DA INDÚSTRIA DE BEBIDAS EM REATOR ANAERÓBIO DE CIRCULAÇÃO INTERNA (IC)
}

\author{
WASTEWATER TREATMENT OF BEVERAGE \\ INDUSTRY IN ANAEROBIC REACTOR FOR INTERNAL \\ CIRCULATION (CI)
}

\author{
José Amaro Sereno Filho \\ jasereno1953@gmail.com \\ Consultor/ANBEM \\ André Felipe de Melo Sales Santos \\ afsconsult@hotmail.com. \\ CETREL S.A. \\ Jackeline Maria Cardoso de França Bahé \\ jackbahe@gmail.com. \\ IFRJ \\ Clarice Neffa Gobbi \\ claricegobbi@gmail.com. \\ UFRJ \\ Gustavo Aveiro Lins \\ gu.lins@terra.com.br \\ SEE-RJ/ CEDERJ \\ Josimar Ribeiro de Almeida \\ jralmeida@usp.br \\ Observatório Urbano/UERJ/UN-Habitat
}

\section{RESUMO}

Os efluentes gerados na indústria de bebidas são ricos em açúcares, possuem $\mathrm{pH}$ alcalino, temperatura ambiente e apresentam elevada carga orgânica (DBO, DQO e sólidos totais), fazendo-se necessário um alto grau de tratamento da água de processo, antes de retorná-la à natureza. Um adequado tratamento irá garantir e assegurar a eco-eficiência, no sentido de evitar ou reduzir os danos ao homem e ao ambiente, assim como, possibilitar o reuso deste efluente tratado, sendo necessária a associação de diversos níveis de tratamento, devido ao elevado grau de complexidade da composição dos efluentes industriais gerados nestas indústrias, que varia de acordo com o processo produtivo, principalmente em função da tecnologia empregada durante as etapas de lavagem, para que se torne efetiva a remoção dos poluentes. O objetivo deste estudo foi verificar a aplicabilidade e a eficiência da tecnologia anaeróbia em uma planta de tratamento de efluentes, composta por tratamento primário em um reator anaeróbio de circulação interna (IC) seguido de tratamento secundário em sistema de lagoa de aeração-polimento, em escala real, de uma indústria de bebidas de grande porte, produtora de cervejas e refrigerantes.

Palavras-chave: Efluentes, Tratamento anaeróbio, Reator 


\begin{abstract}
The effluent generated in the beverage industry is rich in sugar, have an alkaline $\mathrm{pH}$, temperature ambient and have high organic load (BOD, COD and solids) due to the sugar of syrup and vegetable extracts used in the formulation of the drink, making necessary a high degree of water treatment process, before returning it to nature. An appropriate treatment will guarantee and assure the eco-efficiency in order to avoid or mitigate damages to humans and the environment, as well as enable the reuse of treated effluent, being necessary the association of various levels of treatment because of the high degree complexity of the composition of industrial effluents generated in these industries, which varies according to the production process, mainly due to the technology used during the washing steps, to have an effective removal of pollutants. The main objective of this study is to verify the applicability and efficiency of anaerobic technology in a plant of treatment of effluent, consisting of primary treatment in an anaerobic reactor internal circulation (IC) followed by secondary treatment in system of aeration- pond-polishing lagoon, in scale real, of a beverage industry of large-scale, producing beer and soft drinks.
\end{abstract}

Key-words: Effluents, Anaerobic treatment e Reator.

\title{
INTRODUÇÃO
}

A Terra possui 1,4 milhões de quilômetros cúbicos de água, mas apenas $3 \%$ desse total é doce. Os rios, lagos e reservatórios de onde a humanidade retira o que consome só correspondem a $0,3 \%$ desse percentual. Por isso a necessidade de preservação dos recursos hídricos. A água captada para consumo é armazenada em reservatórios de distribuição e depois enviada para tanques e caixas d'água de casas, edifícios e indústrias. Antes de voltar à natureza, ela deve ser convenientemente tratada para evitar ou reduzir os danos ao homem e ao ambiente, assim como possibilitar o reuso do efluente tratado.

No que diz respeito ao segmento industrial de bebidas, a origem dos efluentes provém das etapas de lavagem (seja dos vasilhames, equipamentos ou da instalação em si, das tubulações e pisos), das águas de sistemas de resfriamento, das águas utilizadas diretamente no processo industrial ou incorporadas ao produto, do descarte de produtos defeituosos ou retornados do mercado e dos esgotos sanitários dos funcionários (SANTOS e RIBEIRO, 2005).

Os efluentes gerados na indústria de bebidas são ricos em açúcares, possuem $\mathrm{pH}$ alcalino e temperatura ambiente. Apresentam elevada carga orgânica 
(DBO, DQO e sólidos totais) devido ao açúcar do xarope e dos extratos vegetais utilizados na formulação das bebidas. Entretanto, a caracterização deste efluente varia de acordo com o processo produtivo, principalmente devido à tecnologia empregada durante as etapas de fabricação das bebidas.

Desta forma, em função da elevada carga orgânica e elevado grau de complexidade da composição dos efluentes industriais gerados nestas indústrias, faz-se necessário um alto grau de tratamento da água de processo, exigindo uma combinação de processos para que a remoção dos poluentes seja eficiente.

Em relação ao tratamento biológico desses efluentes tem-se à disposição dois métodos diferentes: tratamento anaeróbio, utilizando microrganismos que independem de oxigênio, e tratamento aeróbio, ao qual se fornece oxigênio para os microrganismos através de aeração.

Para tornar viáveis os processos biológicos para o tratamento de efluentes industriais são necessários equipamentos com elevadas capacidades de tratamento aliados à boa eficiência de remoção dos poluentes orgânicos. $\mathrm{Na}$ prática isso significa que um reator industrial deve ser capaz de trabalhar com altas taxas de carregamentos orgânicos e baixos tempos de detenção.

Os processos mais indicados e utilizados no Brasil para o tratamento deste efluente são compostos por três etapas: tratamento preliminar, tratamento secundário (com prévia correção do $\mathrm{pH}$ e adição artificial de nutrientes, com uso de reatores anaeróbios do tipo UASB ou IC) e pós-tratamento em lagoa aerada seguida de decantação (polimento). As vantagens da associação de um sistema anaeróbio seguido de um aeróbio vêm do fato do sistema anaeróbio promover uma remoção inicial de carga orgânica substancial com baixa geração de lodo. Outra vantagem do sistema é que há geração de metano que pode ser utilizado futuramente como insumo no próprio processo industrial (caldeiras, empilhadeiras).

De acordo com Santos e Ribeiro (2005), antes do tratamento biológico, deve-se 
construir um tanque de neutralização, onde o pH deve ser corrigido próximo à neutralidade para fornecer as condições para o bom desempenho do reator anaeróbio. Ainda no tanque de neutralização, podem ser adicionados os nutrientes (fósforo e nitrogênio) ao efluente, quando necessário. O efluente do reator anaeróbio pode ser recirculado para o tanque de neutralização. Depois do reator anaeróbio, o efluente passa para a etapa aeróbia de pós-tratamento. O tratamento terciário é composto por lagoas de aeração e de decantação. $\mathrm{Na}$ primeira lagoa, a oxigenação do efluente é muito importante na degradação da matéria orgânica. A lagoa de decantação é fundamental para a clarificação final do efluente.

Os parâmetros que determinam a capacidade de um reator anaeróbio podem ser classificados em fatores microbiológicos (atividade microbiana, crescimento microbiano) e físicos (capacidade de retenção de microrganismos, contato efluentes/microrganismos). Os fatores microbiológicos estão ligados a parâmetros fisiológicos como: temperatura, $\mathrm{pH}$, alcalinidade e a presença de compostos inibidores.

Dentre os vários projetos para reatores do tipo EGSB, que buscam eliminar as deficiências encontradas nos reatores UASB, destaca-se o Reator Anaeróbio de Circulação Interna (IC) pela engenhosidade e simplicidade construtiva. $O$ Reator IC consiste basicamente na instalação de dois reatores UASB sobrepostos. O reator inferior recebendo um alto carregamento orgânico e o superior pouquíssimo carregado. Seu trunfo principal é a separação do biogás em dois estágios dentro do reator. O gás coletado no primeiro estágio proporciona o arraste ("gas-lift") de efluente e lodo anaeróbio para o topo do reator de onde são separados e internamente recirculados à parte inferior do reator, procedimento este que Ihe confere o nome (Reator Anaeróbio de Circulação Interna).

Sendo assim, o objetivo deste trabalho é avaliar, através de um estudo de caso, a eficiência da tecnologia anaeróbia em uma planta de tratamento de efluentes de uma indústria de bebidas (cervejas e refrigerantes) de grande porte. O tratamento em questão é composto por tratamento primário em um reator anaeróbio IC, seguido de tratamento secundário em sistema de lagoa de 
aeração-polimento, em escala real.

\section{REVISÃO TEORICA}

\section{REATOR IC}

O Reator IC consiste em um tanque cilíndrico, vertical, com altura variando de 16 a 25 metros e pequena área superficial, com diâmetros variando de 1,0 11,5 metros. O corpo do reator pode ser executado em aço inoxidável ou aço carbono revestido com proteção anticorrosiva. Em ambos os casos há um revestimento interno das paredes em plástico de engenharia, no fundo (evitar erosão na alimentação) e na parte superior para evitar a corrosão causada pela conversão de sulfetos. O teto de lodo na zona de mistura, o tanque separador gás/líquido e as tubulações internas sempre são construídas em aço inoxidável. Os separadores internos são construídos totalmente em plástico de engenharia (polipropileno) e ocupam toda a área superficial do reator. Estes cuidados garantem a longa vida útil do equipamento quando submetidos às condições do processo anaeróbio.

O efluente é bombeado para o reator entrando no sistema de distribuição onde é misturado com o efluente tratado e o lodo anaeróbio recirculados. 0 compartimento inferior do reator abriga a zona de Leito Granulado Expandido, bastante carregada orgânica e hidraulicamente, onde cerca de $70-75 \%$ da DQO são convertidos em biogás. O biogás produzido nessa região é coletado pelo $1^{\circ}$ separador de fases e é utilizado para gerar o "gas-liff" que proporciona o arraste de efluente e lodo via tubulação de subida para o separador gáslíquido instalado no topo do reator. O biogás é separado da mistura efluente/lodo e deixa o sistema. A mistura efluente/lodo é direcionada ao fundo do reator pelo tubo de descida resultando no fluxo de circulação interna. $O$ efluente que atravessa o $1^{\circ}$ separador, livre da grande concentração de biogás, encontra a zona de polimento onde a pequena parcela residual da DQO é degradada atingindo remoções de 75 - 85\%. O biogás produzido nessa área é 
coletado no $2^{\circ}$ separador trifásico instalado na parte superior do reator, enquanto o efluente tratado deixa o reator pelos vertedores.

São cinco as principais características do Reator Anaeróbio de Circulação Interna (IC): a zona de mistura, a zona de leito expandido de lodo anaeróbio granulado, a zona de polimento, o sistema automático de recirculação e a forma/materiais de construção.

Zona de Mistura: No fundo do reator o efluente que chega para o tratamento é efetivamente misturado com o lodo anaeróbio e o efluente da corrente de recirculação. Isto resulta numa diluição e condicionamento do efluente de entrada, minimizando os riscos de toxicidade e choques de carga orgânica e $\mathrm{pH}$.

Zona de Leito Expandido: Contém um leito de lodo anaeróbio granulado expandido altamente concentrado. A expansão/fluidização do leito é efetuada pela elevada vazão ascensional de efluente, recirculação e biogás produzido. $O$ efetivo contato entre o efluente e os microrganismos resulta em uma alta atividade do lodo, que possibilita a aplicação de elevados carregamentos orgânicos com boa eficiência de conversão. Testes comparativos demonstraram que lodos anaeróbios granulados originários de reatores IC freqüentemente apresentavam o dobro da atividade específica metanogênica de lodos de reatores UASB.

Zona de Polimento: O primeiro separador consegue remover a maior parte do biogás produzido na zona de leito expandido. Com isso, garante pouca turbulência na zona de polimento. A vazão de efluente que é recirculada internamente também ficará restrita ao compartimento inferior do reator, entrando na zona de polimento vazão idêntica a de entrada de efluentes no reator. Esses fatores proporcionam uma boa separação sólido/líquido, fazendo com que a biomassa seja retida no reator e o efluente saia clarificado pelos vertedores na parte superior do segundo separador. A pequena vazão de biogás gerada na zona de polimento será coletada e enviada ao tanque separador no topo do reator. 
Sistema de Recirculação: A circulação interna é baseada no princípio do "gas-lift" e é controlada pela vazão de biogás produzida no reator (não é necessária a utilização de bomba). Portanto, a vazão de recirculação depende somente da DQO do efluente de entrada e seu controle é automático: quando maior a DQO, maior produção de biogás na zona de leito expandido, maior vazão de recirculação e também maior diluição do efluente de entrada após a mistura na zona de mistura. Importante reafirmar que a vazão recirculada que permite um melhor contato efluente/microrganismos na zona de leito expandido, é coletada no primeiro separador, garantindo menores velocidades ascensionais previstas no projeto para a zona de polimento.

\section{PARÂMETROS IMPORTANTES NO MONITORAMENTO DE REATORES ANAERÓBIOS}

Alguns parâmetros possuem uma significância maior no monitoramento de reatores anaeróbios por ser um indicativo da eficiência do estágio operacional e de alterações externas ou internas dos processos que ocorrem no seio do reator. Pode-se destacar a alcalinidade, o $\mathrm{pH}$, os ácidos graxos voláteis (AGV's) e a temperatura como os fatores mais preponderantes.

A alcalinidade é um indicativo da capacidade tampão de um determinado sistema e sendo assim, para uma alcalinidade alta, não deve ser entendida que o $\mathrm{pH}$ esteja necessariamente alto (CHERNICHARO, 1997). O sistema carbônico $\left(\mathrm{CO}_{2} / \mathrm{HCO}_{3}{ }^{-} / \mathrm{CO}_{3}{ }^{2-}\right)$ além de garantir o $\mathrm{pH}$ adequado e estável, influi na composição do biogás gerado e sobre o equilíbrio sólido-líquido com relação à precipitação ou dissolução do $\mathrm{CaCO}_{3}$ (ISOLDI et al., 2001). Metcalf e Eddy (1991) sugerem que valores de alcalinidade para que o processo de digestão anaeróbia ocorra de forma ótima devam encontrar-se na faixa de 1000 a 5000 $\mathrm{mg} / \mathrm{l}$.

Foresti (1997), citado por Isoldi et al. (2001), destaca que o monitoramento da alcalinidade em sistemas anaeróbios é mais eficaz que o $\mathrm{pH}$, visto que a escala do primeiro é linear enquanto a do segundo é logarítmica. E sendo assim, 
pequenas alterações de $\mathrm{pH}$ podem representar altos consumos ou produção de alcalinidade alterando significativamente a capacidade tampão do sistema. As interações dos diferentes sistemas ácido/base presentes no sistema de tratamento estão relacionadas com o equilíbrio iônico das espécies ácidas e alcalinas livres, em função do valor do $\mathrm{pH}$.

Segundo Lettinga et al. (1996), citados por Metcalf e Eddy (1991), os efeitos do pH sobre a digestão anaeróbia se manifestam sobre duas vertentes: afetando a atividade microbiana e a toxicidade de vários compostos. As arqueas metanogênicas atuam na faixa ótima de 6,6 a 7,4, as acidogênicas na faixa de 5 a 6. Foresti (1997) e Chernicharo (1997) citados por Isoldi et al. (2001), destacam que a produção de ácidos pode seguir no reator apesar da produção de metano ter sido interrompida devido aos valores reduzidos de $\mathrm{pH}$.

Os ácidos graxos voláteis mantêm uma relação estreita com a alcalinidade. Os ácidos formados no processo tendem a reduzir $\mathrm{o} \mathrm{pH}$ tornando-o ácido $\mathrm{e}$ inadequado aos processos anaeróbios. Neste sentido o efeito tamponante da alcalinidade evita quedas bruscas e oscilações freqüentes do $\mathrm{pH}$. Metcalf e Eddy (1991) sugerem valores para o AGV abaixo de 250 mg/l.

A temperatura interfere diretamente na cinética microbiana. Reatores que operam numa faixa ótima de temperatura, que pode variar em função do inóculo, de condições operacionais e ambientais têm a vantagem da redução de volumes úteis do reator e de eficiências otimizadas. Quedas de temperatura podem provocar aumento do pH visto que a concentração de DQO digerida é reduzida com queda conseqüente da produção de $\mathrm{CO}_{2}$ (LETTINGA et al., 1996 apud CHERNICHARO, 1997).

A avaliação periódica da atividade da massa bacteriana dentro de um reator é uma forma de se detectar possíveis problemas operacionais no sistema. Segundo Poetsch e Koetz (1998), o teste de atividade metanogênica específica (AME) é um dos controles operacionais que mais tem merecido atenção de pesquisadores em todo mundo, visto que ainda não foi objeto de uma padronização, ficando cada grupo de pesquisa livre no uso de métodos mais adequados ao seu trabalho. Alguns métodos encontrados na literatura são 
muito refinados ou caros e outros grosseiros ou imprecisos (CHERNICHARO, 1997). De uma forma geral, o método se baseia na incubação de certa quantidade de biomassa anaeróbia em um meio contendo certa concentração de acetato e nutrientes, a uma determinada temperatura constante (HOSKONING, 1989 apud VAN HANDEL e LETTINGA, 1994; POETSCH e KOETZ, 1998). A quantidade de biogás produzido é devidamente medida por unidade de tempo e por unidade de massa microbiana; e a partir das medições de $\mathrm{CH}_{4}$ realizadas em intervalos de tempo do teste, é possível determinar uma curva cuja maior tangente fornece o valor da atividade metanogênica máxima.

\section{ESTUDO DE CASO E METODOLOGIA}

A indústria em questão produziu em 2008, cerca de 2,8 milhões de hectolitros de cerveja e 1,0 milhão de hectolitros de refrigerantes. O consumo de água

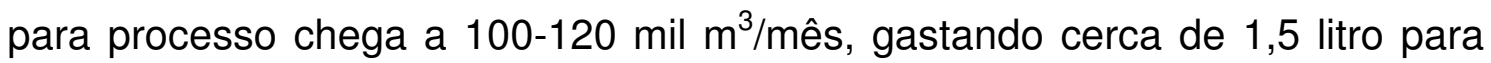
produzir 1 litro de refrigerante e aproximadamente 4,2 litros para produzir 1 litro de cerveja. Na proporção obtida para a produção de cerveja deve-se levar em consideração que parte da produção é envasada em latas de alumínio, o que diminui substancialmente o consumo de água para a obtenção deste produto.

Foi realizada a avaliação da eficiência do sistema de tratamento por três meses de acompanhamento do automonitoramento das análises laboratoriais da estação de tratamento de efluentes. Foram avaliadas apenas as eficiências médias em DQO e DBO do tratamento dos efluentes no reator IC e a eficiência global do sistema após o pós-tratamento em lagoas de aeração/polimento.

A concepção avaliada neste estudo de caso associa um reator anaeróbio tipo IC (leito expandido com circulação interna) com um sistema de lagoa aerada seguida de polimento antes do envio ao corpo receptor final. A remoção da DQO residual do sistema anaeróbio se dá pelo sistema de lagoas aeradas e pelo posterior polimento com a decantação dos sólidos suspensos e decaimento de microrganismos patogênicos (ovos de helmintos, coliformes termotolerantes). As águas residuárias geradas no processo fabril, portanto, são 
encaminhadas para uma estação de tratamento composta por um sistema seqüencial de concepção mista (anaeróbio/aeróbio) que envolve tratamento preliminar e equalização, tratamento primário e tratamento secundário. $\mathrm{Na}$ Tabela 1 são descritas para cada nível as unidades de tratamento, suas características construtivas e funcionais. 
Tabela 1 - Descrição das características e funções das unidades de tratamento (atuais em operação)

\begin{tabular}{|c|c|c|c|}
\hline $\begin{array}{l}\text { Nível de } \\
\text { tratamento }\end{array}$ & Equipamento & Função & Descrição dos equipamentos do sistema de tratamento \\
\hline \multirow{3}{*}{$\begin{array}{l}\text { Pré- } \\
\text { tratamento }\end{array}$} & Peneiras estáticas & $\begin{array}{l}\text { Remover sólidos grosseiros, flutuantes e } \\
\text { areia afluente ao tanque de equalização, } \\
\text { evitar corrosão de tubulações e acúmulo } \\
\text { de sólidos nos tanque e reator. }\end{array}$ & $\begin{array}{l}\text { 2, em concreto armado, com telas em AISI- } 304 \text {, abertura de } \\
0,75 \mathrm{~mm} \mathrm{e} 100 \mathrm{~m}^{3} / \mathrm{h} \text { de vazão afluente cada }\end{array}$ \\
\hline & Calha Parshall & Medição da vazão afluente ao sistema & $\begin{array}{l}\text { 2, em poliéster estruturado em fibra de vidro com garganta de } \\
\text { 6" e medição de vazão por sensor }\end{array}$ \\
\hline & $\begin{array}{l}\text { Tanque de } \\
\text { equalização }\end{array}$ & $\begin{array}{l}\text { Equalizar a vazão afluente e promover a } \\
\text { hidrolise inicial dos compostos } \\
\text { fermentáveis }\end{array}$ & $\begin{array}{l}1 \text {, em concreto armado, formato prismático retangular, de } \\
\text { volume total de } 1054 \mathrm{~m}^{3}\end{array}$ \\
\hline \multirow[b]{2}{*}{ Primário } & $\begin{array}{l}\text { Tanque de } \\
\text { condicionamento }\end{array}$ & $\begin{array}{l}\text { Corrigir pH afluente ao sistema após } \\
\text { regularização da vazão afluente. }\end{array}$ & $\begin{array}{l}\text { 1, em concreto armado, formato prismático retangular com } \\
\text { volume } 148 \mathrm{~m}^{3}\end{array}$ \\
\hline & Reator Anaeróbio IC & Remoção de fração orgânica solúvel. & $\begin{array}{l}\text { 1, em AISI-304, altura, } 21,6 \mathrm{~m}, 4 \mathrm{~m} \text { de diâmetro, em formato } \\
\text { cilíndrico e volume total de } 417 \mathrm{~m}^{3} \text {, TDH mínimo }=2,56 \mathrm{~h} \text {, vazão } \\
\text { máxima }=150-200 \mathrm{~m}^{3} / \mathrm{h} \text {, acoplado à gasômetro de } 5 \mathrm{~m}^{3} \text {, flare } \\
150 \mathrm{~m}^{3} / \mathrm{h} \text { e tanque de lodo de } 148 \mathrm{~m}^{3} \text {, tecnologia DEDINI }\end{array}$ \\
\hline \multirow{2}{*}{ Secundário } & Lagoa aerada & $\begin{array}{l}\text { Remoção da fração orgânica } \\
\text { remanescente ao sistema anaeróbio. }\end{array}$ & $\begin{array}{l}\text { 1, conformada em taludes de inclinação } 1: 2 \text {, revestida em } \\
\text { manta PEAD de } 2 \mathrm{~mm} \text {, com } 3,5 \mathrm{~m} \text { de profundidade, } 76 \mathrm{~m} \text { de } \\
\text { comprimento por } 36 \mathrm{~m} \text { de largura (Nível da água), com volume } \\
\text { útil de } 7500 \mathrm{~m}^{3} \text { e oito aeradorer Wetherford de } 1,5 \mathrm{CV} \\
\text { instalados, TDH mínimo }=50 \mathrm{~h}, \mathrm{TA}=0,12 \mathrm{~kg} \mathrm{DBO} / \mathrm{m}^{3} . \text { dia }\end{array}$ \\
\hline & $\begin{array}{l}\text { Lagoa de } \\
\text { polimento/facultativa }\end{array}$ & $\begin{array}{l}\text { Remoção dos sólidos em suspensão e } \\
\text { decantáveis. Remoção de coliforme e } \\
\text { ovos de helmintos. Estabilização de lodo } \\
\text { aeróbio. }\end{array}$ & $\begin{array}{l}\text { 1, conformada em taludes de inclinação } 1: 2 \text {, revestida em } \\
\text { manta PEAD de } 2 \mathrm{~mm} \text {, com } 2,0 \mathrm{~m} \text { de profundidade, } 92,3 \mathrm{~m} \text { de } \\
\text { comprimento por } 17,2 \mathrm{~m} \text { de largura (Nível da água), com } \\
\text { volume útil de } 3600 \mathrm{~m}^{3} \text {, TDH mínimo= } 24 \mathrm{~h}\end{array}$ \\
\hline
\end{tabular}




\section{CARACTERÍSTICAS DE EFICIÊNCIA DE PROJETO DO SISTEMA DA ESTAÇÃO DE TRATAMENTO DE EFLUENTES AVALIADA}

O projeto do sistema de tratamento de efluentes foi baseado nos padrões aplicados para a tipologia cervejeira de acordo com a experiência previa da DEDINI - Indústria de Base bem como informações da literatura técnica. $\mathrm{Na}$ Tabela 2 são apresentados alguns dados do projeto.

Tabela 2 - Eficiências de Projeto do sistema de tratamento de efluentes.

\begin{tabular}{|c|c|}
\hline $\begin{array}{l}\text { Dados de eficiência do } \\
\text { projeto }\end{array}$ & Valores comuns em sistemas bem operados \\
\hline Eficiência reator IC & $70 \%$ DQO bruta, $85 \%$ DBO solúvel, SSD $<1 \mathrm{~mL} / \mathrm{L}$ \\
\hline $\begin{array}{l}\text { Eficiência } \\
\text { aerada/Polimento }\end{array}$ & $\begin{array}{l}80-90 \% \text { em DQOr, } 80 \% \text { DBOr, } 90 \% \text { em SD, } 90-99 \% \\
\text { coliformes e ovos de helmintos. }\end{array}$ \\
\hline $\begin{array}{l}\text { Percentagem de Metano no } \\
\text { biogás }\end{array}$ & $60-70 \%, 0,35 \mathrm{~m}^{3}$ de $\mathrm{CH}_{4} / \mathrm{kg} . \mathrm{DQOr}(\mathrm{CNTP})$ \\
\hline
\end{tabular}

Fonte: Adaptado de Projeto de sistema de tratamento de efluentes (DEDINI).

\section{AUTOMAÇÃO NO PROCESSO DE TRATAMENTO DE EFLUENTES}

Controles on line favorecem a estabilidade do processo de tratamento e as medidas corretivas automáticas para correção das condições ideais de operação do reator de forma a manter estável a eficiência do processo. A estação de tratamento em questão possui um nível de automação razoável o que permite certa liberdade operacional além das garantias de funcionamento adequado. Algumas unidades de controle auxiliar são: Medidores de $\mathrm{pH}$ on line (peneira estática e entrada do reator); Medidor de nível do tanque de equalização; Controle de dosagem de soda e nutrientes (set points); Controle de vazão on line de afluentes (peneiras, entrada IC) e efluentes (emissário); Controle de nível do tanque de equalização; Acionamento de bombas e aeradores; Controle de vazão afluente ao reator IC.

\section{AÇÕES DE CONTROLE AMBIENTAL - AUTOMONITORAMENTO}

A empresa realiza continuamente um monitoramento dos efluentes (Tabela 3 ) gerados e enviados para o corpo receptor. A empresa possui também um 
moderno laboratório equipado com equipamentos de última geração localizado na própria estação de tratamento que dá suporte ao monitoramento diário de parâmetros de controle ambiental baseados em metodologias analíticas preconizadas pelo Standard Methods for the Examination of Water and Wastewater (AWWA/APHA/WEF, 1995).

A estação é automatizada, controlada e monitorada por operadores continuamente nos três turnos. As eficiências médias de remoção de materia orgânica e sólidos estão situados entre 90 e 96\%. Os efluentes são encaminhados ao corpo receptor. Os resultados do monitoramento diário são encaminhados, trimestralmente, ao órgão ambiental.

Tabela 3 - Análises realizadas no automonitoramento da estação de tratamento de efluentes - ETE

\begin{tabular}{|c|c|c|}
\hline ANÁLISE & FREQUÊNCIA & Método, equipamento \\
\hline DQO & $\begin{array}{lll}\text { Diária } & \text { (com } & \text { amostra } \\
\text { composta } & \text { coletada por cada } \\
\text { turno) } & \end{array}$ & $\begin{array}{l}\text { Colorimétrico, digestão em } \\
\text { fechado. Espectrofotômetro } \\
\text { DR/2010 }\end{array}$ \\
\hline DBO & Semanal & $\begin{array}{l}\text { Manométrica, HACC BOD TRACK, } 6 \\
\text { canais }\end{array}$ \\
\hline Temperatura & À cada duas horas & $\begin{array}{l}\text { Leitura direta, termômetro comum de } \\
\text { vidro com bulbo de mercúrio }\end{array}$ \\
\hline $\mathrm{pH}$ & À cada duas horas & Leitura direta, pHmetro Termo Orion 230 \\
\hline Acidez volátil & $\begin{array}{l}\text { Diária, } 1 \text { vez por turno ( } 3 \text { ao } \\
\text { dia) }\end{array}$ & Titulométrico \\
\hline Alcalinidade Total & $\begin{array}{l}\text { Diária, } 1 \text { vez por turno ( } 3 \text { ao } \\
\text { dia) }\end{array}$ & Titulométrico \\
\hline $\begin{array}{l}\text { Sólidos } \\
\text { Sedimentáveis }\end{array}$ & $\begin{array}{l}\text { Diária, } 1 \text { vez por turno ( } 3 \text { ao } \\
\text { dia) }\end{array}$ & Leitura direta, cone Imoff \\
\hline $\begin{array}{l}\text { Sólidos } \\
\text { suspensos totais }\end{array}$ & Semanal & Filtração \\
\hline Óleos e Graxas & Mensal & Extração por solvente \\
\hline
\end{tabular}

OBS: As metodologias das análises dos efluentes seguem ao Standard Methods for the Examination of Water and Wastewater (AWWA/APHA/WEF, 1995).

As análises de automonitoramento são realizadas no Laboratório da própria unidade fabril que se encontra devidamente aparelhado para a realização das mesmas. Os pontos onde os o automonitoramento é realizado são: Peneira estática; Tanque de equalização; Entrada do Reator IC; Saída do reator IC; Saída da lagoa aerada; Saída da lagoa de polimento. 


\section{RESULTADOS}

Os resultados dos principais parâmetros do automonitoramento da ETE nos meses de janeiro, fevereiro e março de 2009 são apresentados na Tabela 4. $\mathrm{Na}$ Tabela 5 apresentam-se as eficiências médias do sistema de tratamento para o mesmo período. Nas Figuras 1 a 3 são apresentados os gráficos mensais de eficiência de remoção de $D Q O$ e nas Figuras de 4 a 6 são apresentados os gráficos mensais de eficiência de remoção de DBO.

Tabela 4 - Síntese dos resultados médios mensais dos parâmetros de automonitoramento da estação de tratamento de efluentes - ETE

\begin{tabular}{lllllll}
\hline \multirow{2}{*}{ Parâmetros } & \multicolumn{2}{l}{ Janeiro 2009 } & \multicolumn{2}{c}{ Fevereiro 2009 } & \multicolumn{2}{c}{ Março 2009 } \\
& Afluente & Efluente & Afluente & Efluente & Afluente & Efluente \\
\hline pH & 8,35 & 7,71 & 8,42 & 7,85 & 8,22 & 7,99 \\
T $\left({ }^{\circ} \mathrm{C}\right)$ & 37,61 & 29,81 & 37,96 & 29,86 & 37,47 & 29,80 \\
DQO (mg/L) & 2040,07 & 278,78 & 2062,88 & 185,83 & 1795,86 & 175,81 \\
DBO (mg/L) & 1702,00 & 143,80 & 1680,00 & 155,00 & 1264,75 & 89,5 \\
SD (mL/L) & 0,79 & 1,87 & 0,43 & 1,78 & 0,60 & 1,19 \\
DQO/DBO & 1,20 & 1,94 & 1,13 & 1,20 & 1,42 & 1,96 \\
\hline
\end{tabular}

Tabela 5 - Síntese das eficiências médias de remoção de DQO e DBO da ETE

\begin{tabular}{llll}
\hline Parâmetros & Janeiro 2009 & Fevereiro 2009 & Março 2009 \\
\hline Remoção DQO global (\%) & 85,8 & 90,7 & 90,3 \\
Remoção DBO global (\%) & 91,6 & 90,7 & 92,9 \\
Remoção DQO IC (\%) & 81,7 & 81,1 & 85,1 \\
Remoção DBO IC (\%) & 77,9 & 79,5 & 84,5 \\
Vazão (m $\left.{ }^{3} / \mathrm{h}\right)$ & 132,0 & 117,2 & 106,7 \\
\hline
\end{tabular}




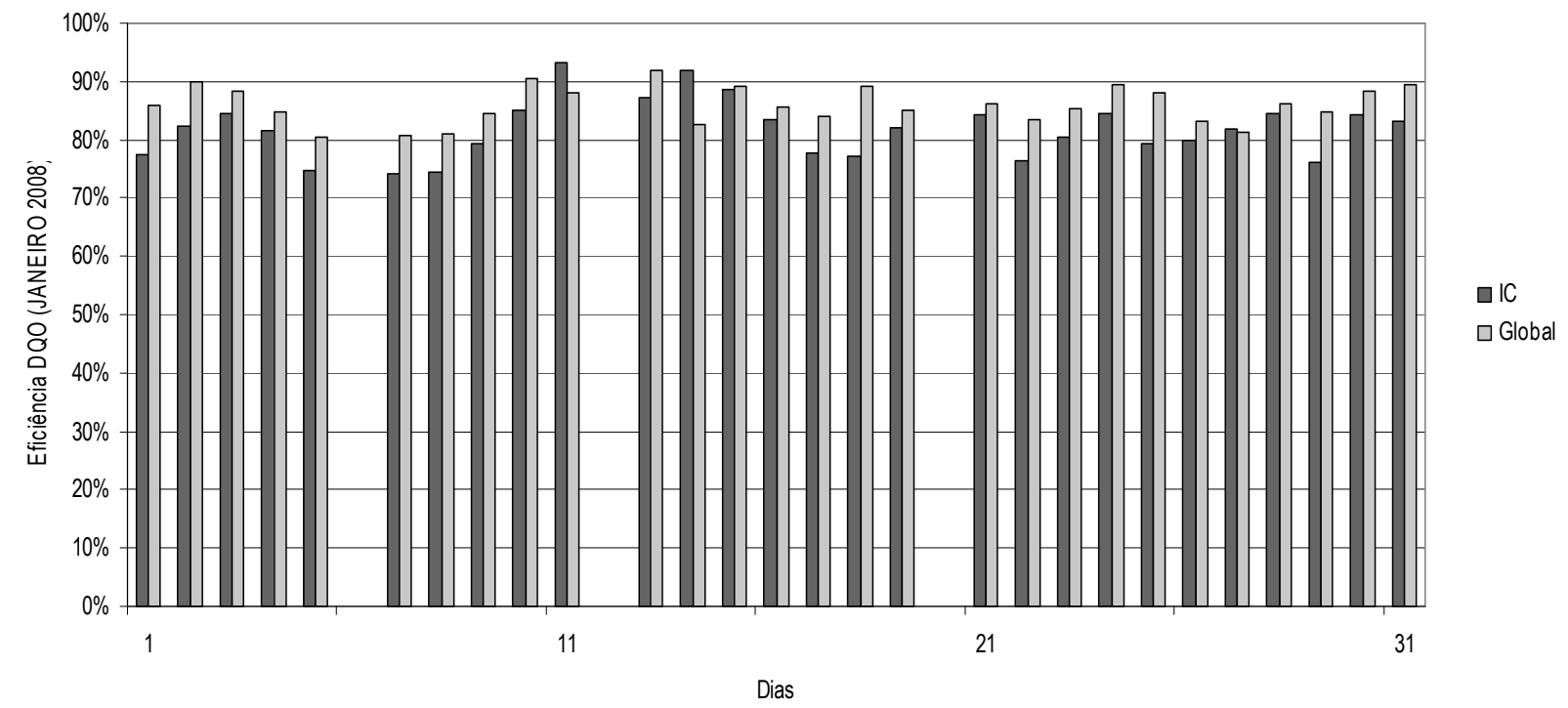

Figura 1 - Eficiências de remoção de DQO diária, referentes ao mês de janeiro de 2009

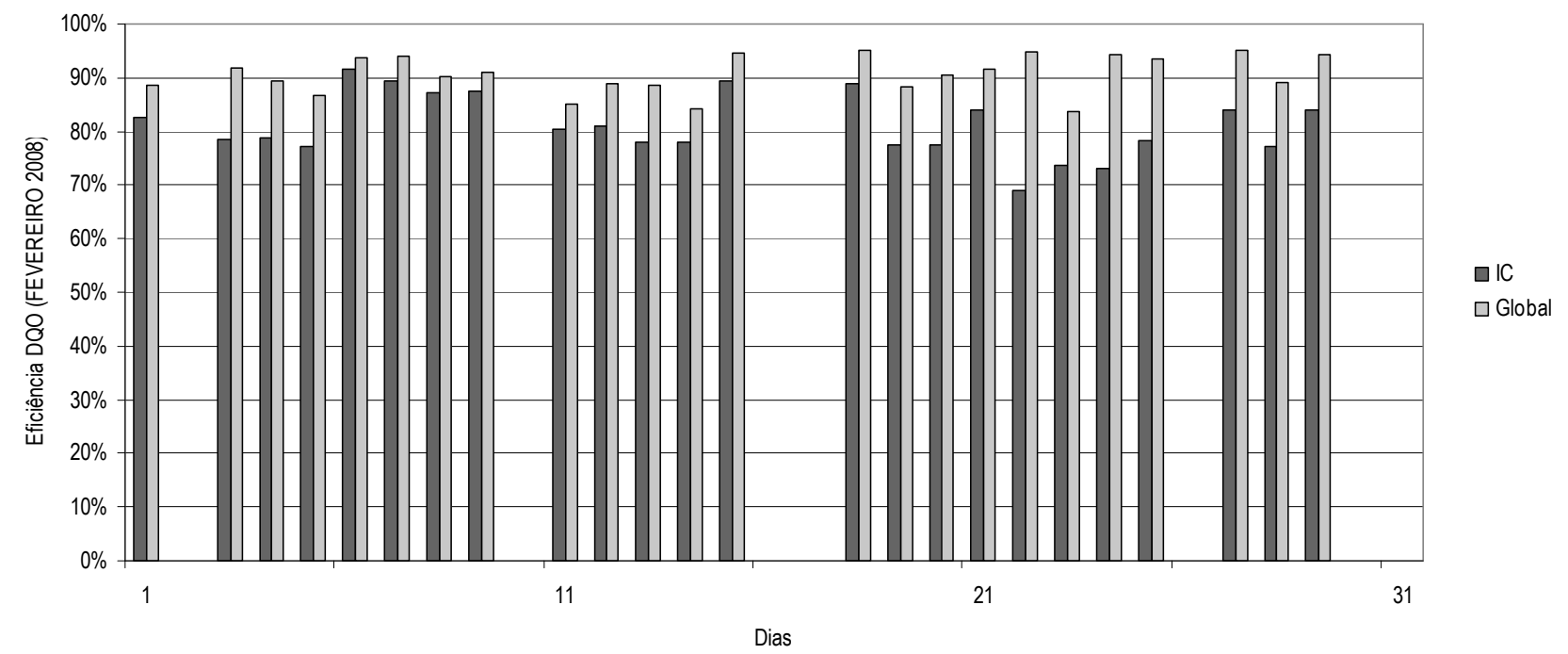

Figura 2 - Eficiências de remoção de DQO diária, referentes ao mês de fevereiro de 2009 


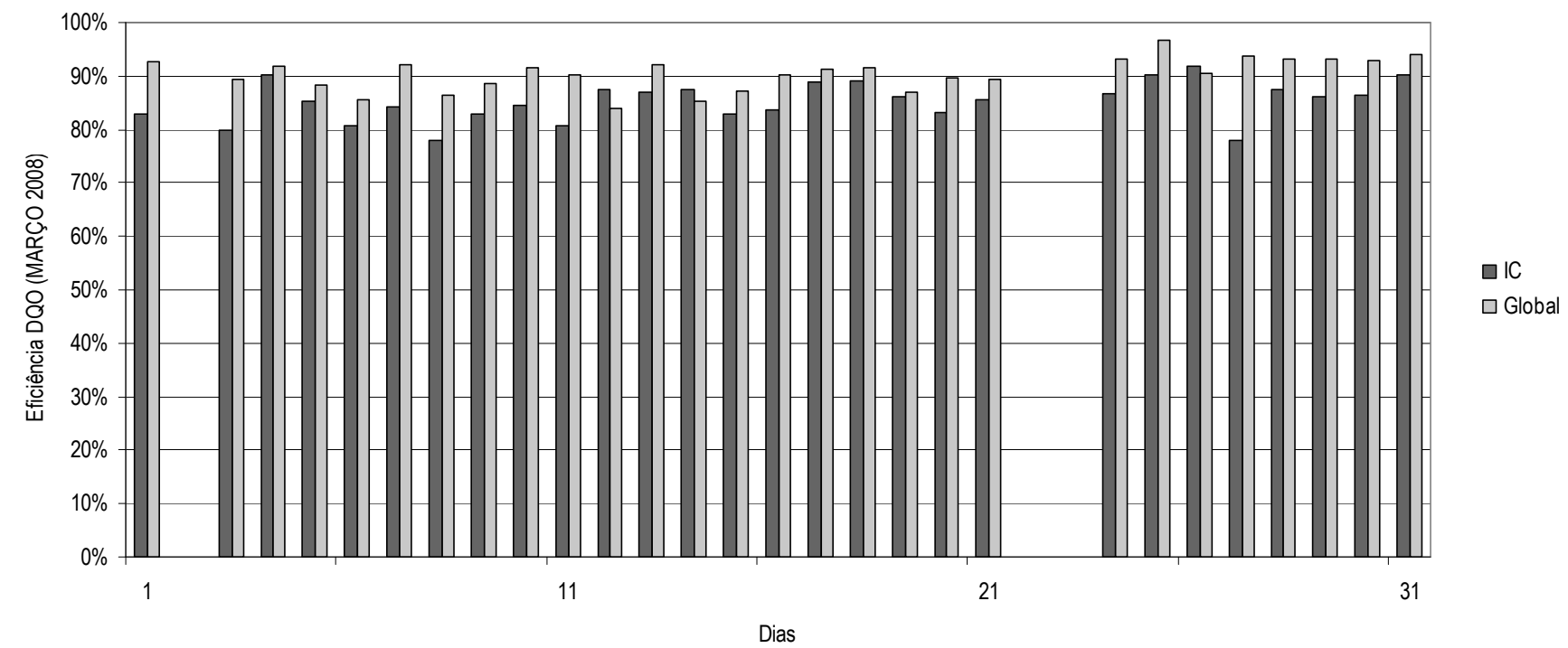

Figura 3 - Eficiências de remoção de DQO diária, referentes ao mês de março

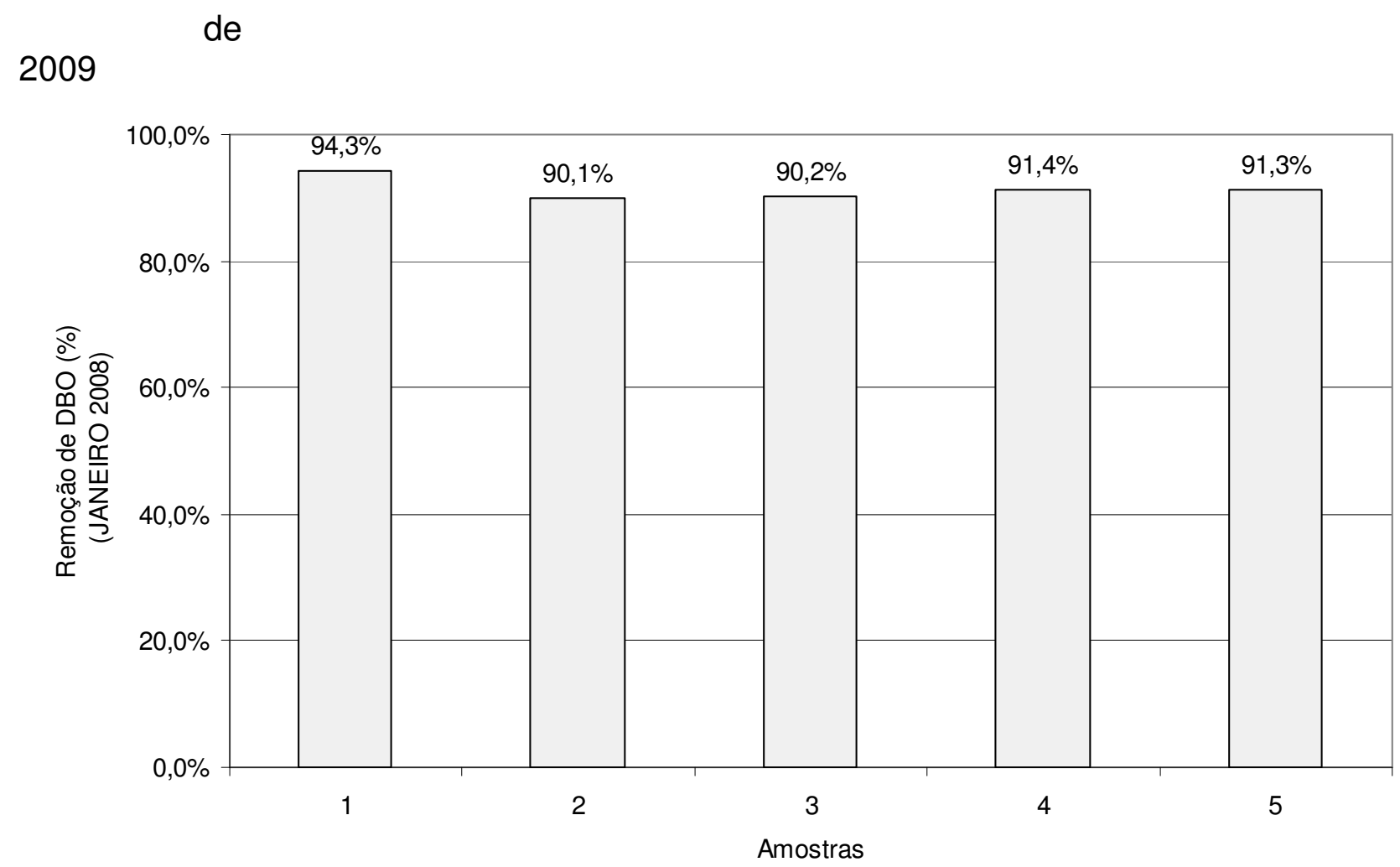

Figura 4 - Eficiências de remoção de DBO, referentes ao mês de janeiro de 2009 


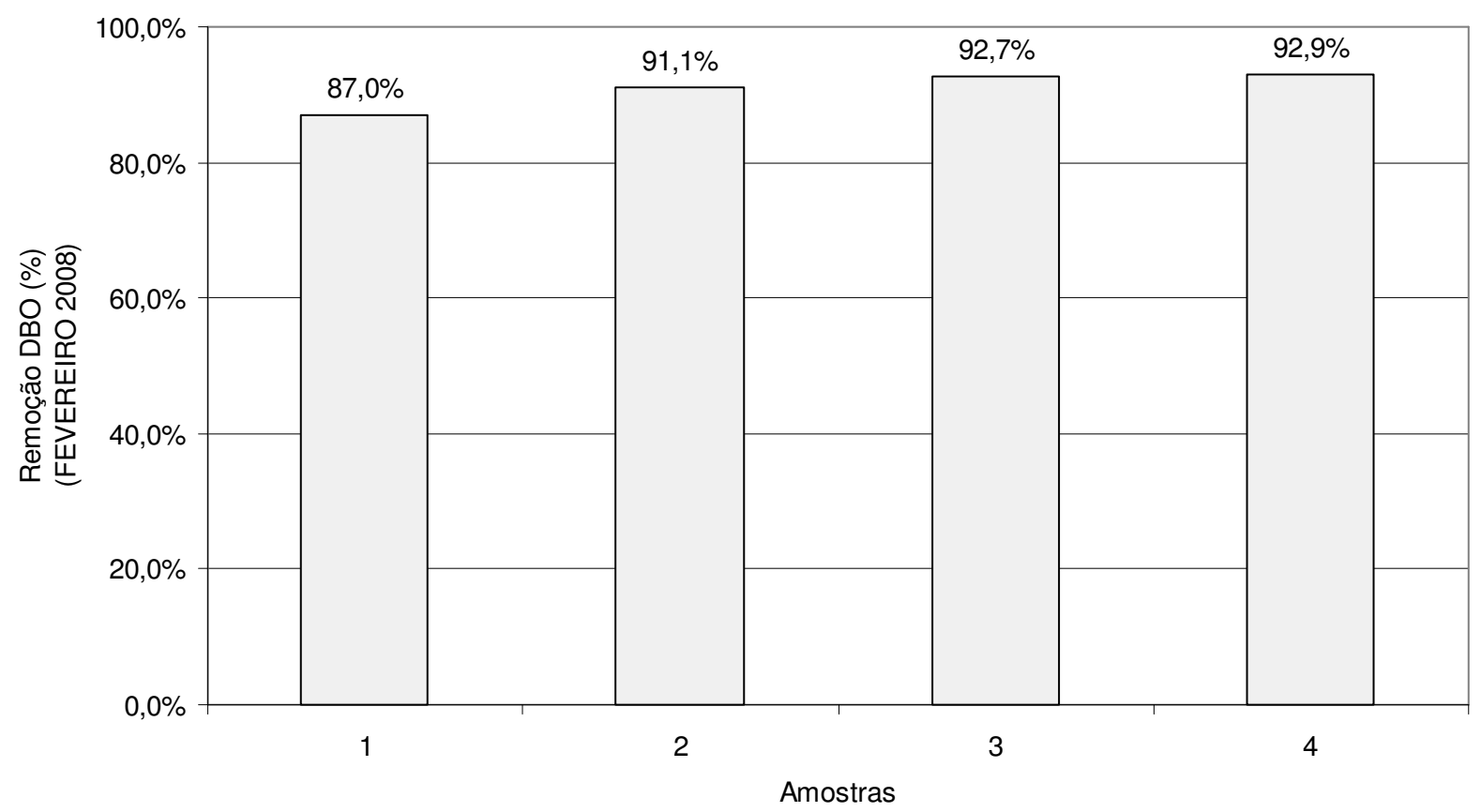

Figura 5 - Eficiências de remoção de DBO, referentes ao mês de fevereiro de 2009

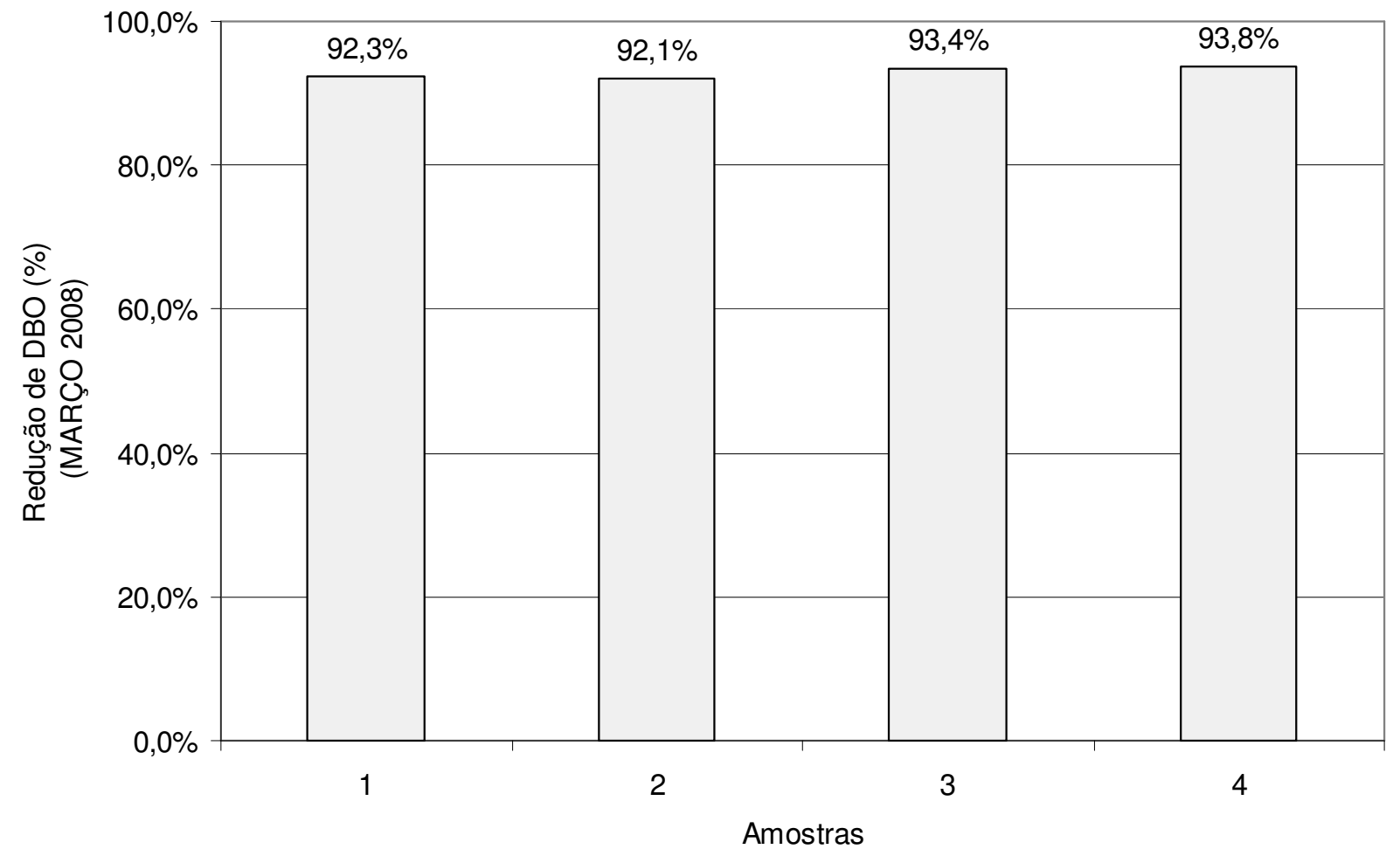

Figura 6 - Eficiências de remoção de DBO, referentes ao mês de Março de 2009 


\section{DISCUSSÃO}

O uso de reatores anaeróbios no tratamento de efluentes das indústrias de bebidas é bastante recomendado pela economia, principalmente nos usos de aeradores (em sistemas como lodos ativados) e pela geração de gás combustível $\left(\mathrm{CH}_{4}\right)$ aproveitável. Porém o uso desses reatores exige um póstratamento por não apresentar-se somente suficiente na remoção completa da matéria orgânica remanescente e ainda, pelo seu efluente possuir baixo nível de oxigênio, cor e odor elevado. No caso específico do Reator Anaeróbio de Circulação Interna (IC) pode-se verificar que este contribuiu para aumentar a viabilidade de implantação do processo anaeróbio para o tratamento de efluentes de indústrias de bebidas, pois apresenta as seguintes vantagens: menor área ocupada, menor suscetibilidade a produtos tóxicos/sobrecargas orgânicas/choques de temperatura e $\mathrm{pH}$ e, principalmente, menor custo de implantação.

As vantagens do tratamento anaeróbio estão no baixo consumo de energia e na pequena geração de lodo excedente, em comparação com o tratamento aeróbio. Aliás, a demanda técnica e a operação são mais complexas no sistema anaeróbio, que se deve ao fato de que o processo biológico é comparativamente mais complexo, onde diferentes microrganismos agem em diferentes meios (faixa de $\mathrm{pH}$, etc). Por este motivo, é pré-requisito que o envio de efluentes à estação de tratamento seja feita sem grandes oscilações (efluente estável), o que nem sempre é possível em pequenas e médias fábricas. Por isso, a limpeza ocorre quase sempre em sistemas de tratamento aeróbios. O sistema de tratamento anaeróbio demanda longo período de tempo para reinício após parada e necessidade de pessoal mais qualificado para a operação do mesmo. Outra desvantagem são os elevados custos de implantação e a necessidade de um controle operacional mais efetivo em função da sensibilidade do sistema a grandes oscilações de carga.

O tratamento de efluentes de concepção anaeróbia, seguido por tratamento aeróbio e polimento aqui avaliado mostrou-se bastante eficiente no tratamento dos efluentes líquidos das indústrias de refrigerantes, porém pode variar de 
acordo com o processo de adotado por cada indústria e também conforme a legislação vigente.

Os custos relacionados à geração de resíduos e emissões, incluindo impactos ambientais negativos e problemas relativos à saúde, e ao entorno (comunidade, corpo receptor, etc.) podem ser evitados ou minimizados através da aplicação ações preventivas e investimento na operação, com a aplicação de normas e procedimentos, além do monitoramento, do treinamento e desenvolvimento do pessoal responsável pela operação do sistema.

Neste estudo de caso observaram-se elevadas eficiências médias de remoção de DQO e DBO, da ordem de 90 a $96 \%$, atendendo aos padrões ambientais do órgão ambiental local, entretanto, oscilações no sistema devido variações da qualidade do efluente, ou problemas ligados a manutenção, provocam oscilações que podem comprometer a qualidade do efluente final e $o$ atendimento às normas e padrões ambientais.

\section{CONCLUSÕES}

A avaliação desse tipo de tecnologia, comumente empregada em indústrias de bebidas de grande porte é bastante positiva apresentando efetivo tratamento com elevadas eficiências de remoção de matéria orgânica e obtenção de efluentes compatíveis com as exigências ambientais legais atuais.

O tratamento anaeróbio mostra-se como uma alternativa viável ao tratamento de efluente para a tipologia bebidas (cervejas e refrigerantes).

Há necessidade do comprometimento de todos os setores industriais no lançamento de produtos na rede de esgotos interna de forma a garantir sua gestão e minimizar impactos que reduzem a eficiência de tratamento do efluente podendo comprometer a qualidade ambiental do efluente final para 0 corpo receptor. Altos investimentos iniciais e controle operacional rígido são 
necessários para a manutenção e monitoramento da estação de tratamento de efluentes.

\section{REFERÊNCIAS}

BRITO, A. G.; MELO, L. F. A simplified analysis of reaction and mass transfer in UASB and EGSB reactors. Environmental Technology. v. 18, p. 35-44. 1997.

CETESB- COMPANHIA DE TECNOLOGIA DE SANEAMENTO AMBIENTAL. Nota técnica sobre tecnologia de controle: Fabricação de cervejas e refrigerantes, NT-24, CETESB, São Paulo, 1992.- 27p.

CETESB. Caso de Sucesso no 24: Redução do consumo de água na indústria de bebidas, CETESB, São Paulo, 2003.

FARIAS, M.S.S. et al. Caracterização dos resíduos líquidos de indústrias de cerveja e a medidas mitigadoras de impactos. Goiânia: Centro Cientifico Conhecer. 2008.2 Disponível em: $<$ <ttp://www.conhecer.org.br/enciclop>. Acesso em 07/11/2009.

MORGAN, S.A.; GASTUME, J. M.; JIMÉNEZ, B.; NOYOLA, A. Tracer studies in a laboratory and pilot scale UASB reactor. Environmental Technology. $v$. 18, p. 817-825. 1997.

ONAY, T.T.; POHLAND, F.G. In Situ nitrogen management in controlled bioreactor landfills. Water Research. v. 32, n. 5, p. 1383-1392.1998.

POHLAND F.G.; KAMG, S.J. Anaerobic Processes. Journal WPCF. v. 43, n. 6, p. 1129-1134. 1971.

SANTOS, M.S.; RIBEIRO, F.M. Cervejas e refrigerantes. São Paulo: CETESB, 2005.58p. Disponível em:<http://www.cetesb.sp.gov.br>. Acesso em 07/11/2009. 
SILVEIRA, B.I. et al. Avaliação do Desempenho de um Reator UASB de uma Planta Industrial de Tratamento de Efluentes Líquidos. IN: $1^{\circ}$ International Workshop Advances in Cleaner Production. São Paulo: UNIP. 2007. Disponível em: www.advancesincleanerproduction.net>. Acesso em 03/11/2009.

STRYDOM,J.P.; BRITZ T.J.; MOSTERT, J.F. Two-phase anaerobic digestion of three different dairy effluents using a hybrid bioreactor. Water SA. v. 23, n.2, p. 151-156. 1997.

VON SPERLING, M. Análise dos padrões brasileiros de qualidade de corpos d'água e de lançamento de efluentes líquidos. Revista Brasileira de Recursos Hídricos. v. 3, n.1, p.111- 132. 1998. 